Journal of Applied Pharmaceutical Science Vol. 6 (02), pp. 097-103, February, 2016

Available online at http://www.japsonline.com

DOI: $10.7324 /$ JAPS.2016.60214

ISSN 2231-3354 (cc) BY-NC-SA

\title{
The Median Time to Develop Recurrent Tuberculosis at a Tertiary Hospital in Kota Bharu, Kelantan, Malaysia
}

\author{
Nyi Nyi Naing ${ }_{5}$, Myat Moe Thwe Aung $^{2 *}$, Abdullah Mohamed Rusli ${ }^{3}$, Mat Jaeb Mat Zuki ${ }^{4}$, Nadiah Wan-Arfah ${ }^{1}$, \\ Mainul Haque \\ ${ }^{1}$ Unit of Biostatistics and Research Methodology, School of Medical Sciences, Universiti Sains Malaysia, 16150 Kubang Kerian, Kelantan, Malaysia. \\ ${ }^{2}$ Universiti Sultan Zainal Abidin (UniSZA), Faculty of Medicine and Health Sciences (FPSK), Jalan Sultan Mahmud 20400, Kuala Terengganu, \\ Terengganu, Malaysia. ${ }^{3}$ Department of Community Medicine, School of Medical Sciences, Universiti Sains Malaysia, 16150 Kubang Kerian, Kelantan, \\ Malaysia. ${ }^{4}$ Respiratory Specialist, Chest Clinic, Department of Medicine, Hospital Raja Perempuan Zainab II, 15000 Kota Bharu, Kelantan, Malaysia. ${ }^{5}$ Unit \\ of Pharmacology, FPSK, UniSZA, 20400 Kuala Terengganu, Terengganu, Malaysia.
}

\section{ARTICLE INFO}

\section{Article history:}

Received on: $12 / 11 / 2015$

Revised on: 30/11/2015

Accepted on: 19/12/2015

Available online: 27/02/2016

Key words:

Tuberculosis, Kaplan-Meier,

Median time, Recurrent,

Malaysia.

\begin{abstract}
This study has the intention to determine the median time to develop recurrent tuberculosis [TB] in TB patients attending the Chest Clinic at Hospital Raja Perempuan Zainab II [HRPZ II], Kelantan, Malaysia. Records of 114 recurrent TB patients from 1/1/2003-31/12/2009 were analyzed. Kaplan-Meier analysis was used to examine the median time for recurrence of TB. The overall median time to develop TB recurrence in registered TB recurrent patients was six months [95\%CI: 4.58, 7.42] after the previous episode. It was found that recipients of Streptomycin (S), Isoniazid (H) and Rifampicin (R) twice weekly $\left(\mathrm{S}_{2} \mathrm{H}_{2} \mathrm{R}_{2}\right)$ drug regimen $[p=0.026]$ or daily HR drug regimen $[p=0.049]$ during the continuation phase took a longer duration to develop recurrent TB than nonrecipients of these medicines by Kaplan-Meier analysis. Moreover, there also existed a significant time difference $[P=0.006]$ between the defaulters and non-defaulters of treatment to develop recurrent TB. Patients should take the complete course of therapy, to reduce recurrent TB infection. The drug regimens must contain the two most potent first line drugs Isoniazid $[\mathrm{H}]$ and Rifampicin $[\mathrm{R}]$ during the continuation phase.
\end{abstract}

\section{INTRODUCTION}

Tuberculosis (TB) remain as a potential killer for mankind killer from the prehistoric time (Daniel, 2006). Evidence suggest that TB has been present for at least 15,000 years. It has been reported that TB affecting humans bones dated back to 2400-3400 BC (Iseman, 2013). TB was epidemics in many countries which includes "Europe and North America in $18^{\text {th }}$ and $19^{\text {th }}$ centuries" and then subsided with the invention of streptomycin and isoniazid (Daniel, 2006). Consequently, TB declined slowly in the developed countries. TB has reappeared as a potential killer again with the emergence of HIV and AIDS (Daniel, 2006). "TB is, thus, the leading cause of mortality in people with HIV/AIDS, and HIV contributes to a substantial proportion of tuberculosis deaths" (Chaisson \& Churchyard, 2010). Globally, every year more than 8-9 million people are newly infected (Uddin et al., 2006). Therefore, in 1995, the

\footnotetext{
* Corresponding Author

Email: myat1979.august@gmail.com
}

World Health Organization launched the Directly Observed Treatment Short-course (DOTS) strategy for control of TB (WHO, 2006). Recurrence of TB is an important indicator to evaluate the current TB control program. Relapses are the primary cause of TB recurrences (Millet et al., 2013). "True relapse can only occur when TB persists after treatment despite apparent cure" and mainly due to inadequate treatment, either due to irrational combination of medicines and duration of treatment (Lambert et al., 2003).

Recurrences can also occur with a different strain (Lambert et al., 2003; Fine \& Small, 1999; Van Rie et al., 1999). Globally, the total number of re-treated cases under DOTS programs in 2008 was 775403 (WHO, 2010). Multple studies suggest that recurrent $\mathrm{TB}$ is significantly related with drugresistance and has lower cure rates. Recurrent $\mathrm{TB}$ is a major clinical problem to cure and control (Cox et al., 2006; El Sahly et al., 2004; Mallory et al., 2004; Panjabi et al., 2007).

The recurrent $\mathrm{TB}$ are more expensive to treat and consume major portion national budgets. Only $61 \%$ of registered recurrent TB successfully treated in Malaysia (WHO, 2013). 
According to the Infectious Disease Act, 342, 1988, of Malaysia all diagnosed new case of TB should be within one of diagnosis (The Ministry of Health, 2012). The number of retreated of TB cases in 2009 was 1181 in Malaysia.

Among these 1181 re-treated patients $36 \% 2 \%, 16 \%$, and $46 \%$ were due to relapse, recurrences after failure, recurrences after default, and others respectively (WHO, 2013). The current study is conducted to determine the median time to develop recurrent TB in patients.

There are only a few studies has been conducted in this regard. Therefore, the findings of the current study will contribute more data about the risk of recurrent TB.

\section{MATERIALS and METHODS}

\section{Study Design}

The study was conducted by retrospective record review to address the median time to develop recurrent TB patients.

\section{Study Participants}

18 years old and above TB patients who must have taken at least one month previous TB therapy. ii. Those who received retreatment therapy for TB disease. TB in these patients was diagnosed and treated by the clinical, radiological and/or bacteriological evidences according to the control and management of TB guidelines of the Ministry of Health, Malaysia (The Ministry of Health, 2012).

Although, the calculated sample size was 120, there was a scantiness of patients. Therefore, no sampling method was applied. 114 patients who fulfilled the inclusion and exclusion criteria were incorporated in this study. The patients who are below 18 years and do not receive anti-tubercular treatment and retreatment were excluded.

\section{Study Area}

The study was conducted at the Chest Clinic in 920bedded HRPZ II Hospital in Kota Bharu having estimated the population of 577301 in 2009.

\section{Data Collection}

Researchers with the help of the staff retrieved the data of recurrent cases registered at the Chest Clinic of HRPZ II, by using the proforma documents from June to July 2010.

\section{Case Definitions}

The case definitions were used according to the Malaysia practice guideline for the control and management of TB except those for defaulter case and recurrent TB case (The Ministry of Health, 2012). A patient who took the previously anti-tubercular therapy for at least one month and then missed more than six doses of daily treatment or more than two doses of biweekly treatment was considered as a defaulter case. A patient who had the previous history of TB disease regardless of pulmonary involvement and sputum smear results and has developed another episode after complete treatment or treatment failure or after default was defined as a relapse or recurrent or re-treatment case. The survival time was referred to re-take another round of treatment with a TB patient.

\section{Statistical Analysis}

Data entry and analysis were performed by using SPSS software version 18 . The median survival time with $95 \%$ confidence intervals for recurrence the TB incidents was determined by the use of the Kaplan-Meier analysis. Categorical independent variables with two levels. The $P$ value was set at $<$ 0.05 .

Regarding variables with more than two levels, pair-wise comparison result. A $P$ value was compared with Bonferronicorrected alpha level.

\section{Ethical Approval}

This study had obtained ethical approvals from Universiti Sains Malaysia [USMKK/PPP/JEPeM \{224.4.\} (2.7), Date: 29 July 2010] and National Medical Research Registry [NMRR: 6300S1, Date: July 20, 2010] from the Ministry of Health, Malaysia.

\section{RESULTS}

There were altogether 363 recurrent TB cases at HRPZ II from 01/01/2003-31/12/2009. However, only 114 records were retrieved (Table 1). The remaining cases had inadequate information and official papers were damaged. Among 114 records, $93.86 \%$ had only one previous episode, and the other $6.14 \%$ had between 2-3 episodes of TB. Those with more than 1 previous TB infection, data of the most recent infection was collected. The survival time was "duration between the last date of previous therapy and the first date of taking treatment for the next infection."

All patients received the intensive phase of TB treatment during which some patients took more than one drug regimen. 21 patients took SHRZ regimen, 84 patients received EHRZ regimen, and 12 patients took HRZ regimen. The median (IQR) duration to receive the treatment for SHRZ, EHRZ, and HRZ regimens were 2.0 (0.0), 2.0 (1.0), 2 (1.8) months respectively. Thirty-six patients $(31.6 \%)$ did not take the treatment for the continuing phase, and during that period, some patients had to take more than one treatment regimen as in the previous stage.

The $\mathrm{H}_{2} \mathrm{R}_{2}$ regimen was given to 26 patients, 14 people got $\mathrm{S}_{2} \mathrm{H}_{2} \mathrm{R}_{2}$ regimen, 40 people got $\mathrm{HR}$ regimen, and 7 people took the other drug regimens. The (IQR) months to take the treatment for $\mathrm{H}_{2} \mathrm{R}_{2}, \mathrm{~S}_{2} \mathrm{H}_{2} \mathrm{R}_{2}, \mathrm{HR}$ and other drug regimens were 4.5 (2.3), 4.0 (2.3), 5.5 (5.0) and 4.0 (7.0) correspondingly. With regard to treatment compliance, 60 patients $(52.6 \%)$ defaulted and did not take the complete course of therapy. 
Table 1: Median Time to get recurrent TB according to sociodemographic features $(n=114)$.

\begin{tabular}{|c|c|c|c|c|}
\hline $\begin{array}{l}\text { Sociodemographic } \\
\text { Characteristics }\end{array}$ & & Frequency (\%) & $\begin{array}{c}\text { Median Time } \\
\text { Months (95\% CI) }\end{array}$ & $p$-value \\
\hline \multirow{2}{*}{ Gender } & Male & $95 \quad(83.3)$ & $6 \quad(4.21,7.79)$ & 0.268 \\
\hline & Female & $19 \quad(16.7)$ & $6 \quad(3.16,8.84)$ & \\
\hline \multirow{2}{*}{ Age } & $<40$ & $64 \quad(56.1)$ & $\begin{array}{ll}6 & (4.19,7.81) \\
\end{array}$ & 0.954 \\
\hline & $\geq 40$ & $50 \quad(43.9)$ & $(2.69,7.31)$ & \\
\hline \multirow{3}{*}{ Marital Status } & Single & $41 \quad(36.0)$ & $(2.49,7.51)$ & 0.340 \\
\hline & Married & $53 \quad(46.5)$ & $7 \quad(3.96,10.04)$ & 0.112 \\
\hline & Divorced & $20 \quad(17.5)$ & $4 \quad(1.81,6.19)$ & \\
\hline \multirow{3}{*}{ Race } & Malay & $110 \quad(96.5)$ & $(3.60,6.40)$ & 0.339 \\
\hline & Chinese & $\begin{array}{ll}3 & (2.6) \\
\end{array}$ & $12 \quad(0.00,24.80)$ & 0.449 \\
\hline & Siamese & $\begin{array}{ll}1 & (0.9) \\
\end{array}$ & $18 \quad(-,,-)^{*}$ & \\
\hline \multirow{2}{*}{ DM } & Absent & $101 \quad(88.6)$ & $5 \quad(3.36,6.64)$ & 0.895 \\
\hline & Present & $13 \quad(11.4)$ & $(3.65,8.35)$ & \\
\hline \multirow{2}{*}{ Liver Disease } & Absent & $113 \quad(99.1)$ & $6 \quad(4.58,7.42)$ & 0.665 \\
\hline & Present & $(0.9)$ & $13 \quad(-,,-)^{*}$ & \\
\hline \multirow{2}{*}{ Smoking } & Absent & $42 \quad(36.8)$ & $6 \quad(3.89,8.12)$ & 0.525 \\
\hline & Present & (63.2) & $(3.08,6.92)$ & \\
\hline \multirow{2}{*}{ Alcohol dependent } & Absent & $102 \quad(89.5)$ & $(4.26,7.74)$ & 0.866 \\
\hline & Present & $12 \quad(10.5)$ & $5 \quad(3.30,6.70)$ & \\
\hline \multirow{2}{*}{ Drug Addict } & Absent & $59 \quad(51.8)$ & $(4.95,9.05)$ & 0.145 \\
\hline & Present & $55 \quad(48.2)$ & $(3.70,6.30)$ & \\
\hline \multirow{2}{*}{ HIV } & Absent & $45 \quad(39.5)$ & $(4.82,9.18)$ & 0.300 \\
\hline & Present & $69 \quad(60.5)$ & $(2.97,7.03)$ & \\
\hline \multirow{2}{*}{ Other diseases } & Absent & $98 \quad(86.0)$ & $(3.24,6.76)$ & 0.967 \\
\hline & Present & $16 \quad(14.0)$ & $7 \quad(4.06,9.94)$ & \\
\hline
\end{tabular}

*95\% Confidence Interval could not be determined.

Log-Rank test was applied.

Table 2: Median Time to get recurrent TB according to Laboratory and Radiographic characteristics $(n=114)$.

\begin{tabular}{|c|c|c|c|c|c|c|}
\hline \multirow{2}{*}{\multicolumn{2}{|c|}{ Laboratory and radiographic Characteristics }} & \multirow{2}{*}{\multicolumn{2}{|c|}{ Frequency $(\%)$}} & \multirow{2}{*}{\multicolumn{2}{|c|}{$\begin{array}{l}\text { Median Time } \\
\text { Months (95\% CI) }\end{array}$}} & \multirow{2}{*}{$P$-value } \\
\hline & & & & & & \\
\hline \multirow{2}{*}{ Value of ESR } & $<104$ & 42 & $(36.8)$ & 7 & $(4.63,9.37)$ & \multirow{2}{*}{0.405} \\
\hline & $\geq 104$ & 41 & $(36.0)$ & 5 & $(2.31,7.69)$ & \\
\hline Not done or missing data & & 31 & $(27.2)$ & & & \\
\hline \multirow{3}{*}{ BCG scar } & Absent & 21 & (18.4) & 6 & $(3.01,8.99)$ & \multirow{2}{*}{0.533} \\
\hline & Present & 92 & $(80.7)$ & 5 & $(3.43,6.57)$ & \\
\hline & Missing data & & $(0.9)$ & & & \\
\hline \multirow{2}{*}{ Tuberculin test results } & Negative & 23 & $(20.2)$ & 3 & $(2.33,3.67)$ & \multirow{2}{*}{0.101} \\
\hline & Positive & 16 & $(14.0)$ & 12 & $(9.47,14.53)$ & \\
\hline Not done or missing data & & 75 & $(65.8)$ & & & \\
\hline \multirow{2}{*}{ Sputum culture results } & Negative & 8 & $(7.0)$ & 5 & $(3.66,6.34)$ & \multirow{2}{*}{0.334} \\
\hline & Positive & 12 & $(10.5)$ & 5 & $(3.33,6.67)$ & \\
\hline Not done or missing data & & 94 & $(82.5)$ & & & \\
\hline \multirow{2}{*}{ First time sputum smear results } & Negative & 33 & $(28.9)$ & 9 & $(5.25,12.57)$ & \multirow{2}{*}{0.491} \\
\hline & Positive & 66 & $(57.9)$ & 5 & $(3.88,6.12)$ & \\
\hline Not done or missing data & & 15 & (13.2) & & & \\
\hline \multirow{5}{*}{ Amount of sputum smear positivity for 66 patients } & $1-49 / 3 \mathrm{~L}(+)$ & 26 & $(39.4)$ & 5 & $(3.03,6.98)$ & \\
\hline & $50 />1 \mathrm{~L}(++)$ & 8 & $(12.1)$ & 4 & $(0.00,10.93)$ & 0.906 \\
\hline & $11-49 / \mathrm{L}(+++)$ & 2 & $(3.0)$ & 5 & $(-, \quad-)^{*}$ & 0.626 \\
\hline & $>50 / \mathrm{L}(++++)$ & 26 & $(39.4)$ & 4 & $(2.34,5.66)$ & 0.197 \\
\hline & Missing data & 4 & $(6.1)$ & & & \\
\hline \multirow[t]{2}{*}{ X-ray results } & No lesion & 18 & (15.8) & 3 & $(0.62,5.38)$ & \\
\hline & Minimal lesion & 62 & $(54.4)$ & 7 & $(4.63,9.37)$ & 0.696 \\
\hline Moderately advanced lesion & & 27 & $(23.7)$ & 4 & $(2.30,5.70)$ & 0.500 \\
\hline \multirow[t]{2}{*}{ Far advanced lesion } & & 4 & $(3.5)$ & 9 & $(1.16,16.84)$ & 0.180 \\
\hline & Missing data & 3 & $(2.6)$ & & & \\
\hline
\end{tabular}

*95\% Confidence Interval could not be determined.

Log-Rank test was applied.

The overall median developing time was 6 months [95\% CI: 4.58, 7.42] for TB recurrence in patients of the current study (Figure 1). There were statistically significant differences $[p=$ 0.026] found between the recipients and non-recipients of $\mathrm{S}_{2} \mathrm{H}_{2} \mathrm{R}_{2}$ drug regimen, and also between the recipients and non-recipients of daily HR drug regimen $[p=0.049]$ during the continuation phase of Kaplan-Meier analysis. Moreover, there was a considerable time difference $(p=0.006)$ between defaulters and non-defaulters of treatment to get recurrent TB. The time to develop recurrent $\mathrm{TB}$ was statistically significant between defaulters and non-defaulters [Table 1, 2, 3 and Figure 2a, b, c]. 
Table 3: Median Time to recurrent TB according to the treatment regiments and compliance factors $(\mathrm{n}=114)$.

\begin{tabular}{|c|c|c|c|c|c|c|}
\hline \multicolumn{2}{|c|}{ Treatment and compliance factors } & \multicolumn{2}{|c|}{ Frequency $(\%)$} & \multicolumn{2}{|c|}{$\begin{array}{c}\text { Median Time } \\
\text { Months (95\% CI) }\end{array}$} & $P$-value \\
\hline \multicolumn{7}{|l|}{ In The Intensive Phase } \\
\hline \multirow{2}{*}{ SHRZ Drug } & Taken & 21 & $(18.4)$ & 7 & $(4.31,9.69)$ & 0.202 \\
\hline & Not taken & 93 & $(81.6)$ & 5 & $(3.43,6.57)$ & \\
\hline \multirow{2}{*}{ Duration of taking SHRZ regimen } & $\leq 2$ months & 17 & $(14.9)$ & 8 & $(5.35,10.65)$ & 0.659 \\
\hline & $\geq 3$ months & 4 & $(3.5)$ & 4 & $(0.00,8.90)$ & \\
\hline \multirow{2}{*}{ EHRZ Drug } & Taken & 84 & $(73.7)$ & 5 & $(3.37,6.63)$ & 0.370 \\
\hline & Not taken & 30 & $(26.3)$ & 7 & $(3.78,10.22)$ & \\
\hline \multirow{2}{*}{ Duration of taking EHRZ regimen } & $\leq 2$ months & 52 & $(45.6)$ & 5 & $(2.88,7.12)$ & 0.988 \\
\hline & $\geq 3$ months & 32 & $(28.1)$ & 5 & $(3.16,6.84)$ & \\
\hline \multirow{2}{*}{ HRZ Drug } & Taken & 12 & $(10.5)$ & 5 & $(0.00,12.92)$ & 0.187 \\
\hline & Not taken & 102 & $(89.5)$ & 6 & $(4.52,7.48)$ & \\
\hline \multirow{2}{*}{ Duration of taking HRZ regimen } & $\leq 2$ months & 8 & $(7.0)$ & 5 & $(0.00,15.16)$ & 0.391 \\
\hline & $\geq 3$ months & 4 & (3.5) & 2 & $\left(\begin{array}{ll}- & -\end{array}\right)^{*}$ & \\
\hline \multirow{2}{*}{ Other drug regimens } & Taken & 8 & $(7.0)$ & 7 & $(0.00,16.24)$ & 0.189 \\
\hline & Not taken & 106 & $(93.0)$ & 5 & $(3.56,6.44)$ & \\
\hline \multirow{2}{*}{ Duration of taking other drug regimens } & $\leq 2$ months & 4 & $(3.5)$ & 3 & $\left(\begin{array}{ll}- & -\end{array}\right)^{*}$ & 0.784 \\
\hline & $\geq 3$ months & 4 & $(3.5)$ & 13 & $(7.91,18.09)$ & \\
\hline \multicolumn{7}{|l|}{ In The Continuation Phase } \\
\hline \multirow{2}{*}{$\mathrm{H}_{2} \mathrm{R}_{2}$ regimen } & Taken & 26 & $(22.8)$ & 5 & $(3.03,6.98)$ & 0.414 \\
\hline & Not taken & 88 & $(77.2)$ & 6 & $(4.28,7.72)$ & \\
\hline \multirow{2}{*}{ Duration of taking $\mathrm{H}_{2} \mathrm{R}_{2}$ regimen } & $\leq 4$ months & 13 & $(11.4)$ & 4 & $(2.24,5.76)$ & 0.605 \\
\hline & $\geq 5$ months & 13 & (11.4) & 5 & $(2.65,7.35)$ & \\
\hline \multirow{2}{*}{$\mathrm{S}_{2} \mathrm{H}_{2} \mathrm{R}_{2}$ regimen $^{\mathrm{a}}$} & Taken & 14 & $(12.3)$ & 8 & $(2.50,13.50)$ & 0.026 \\
\hline & Not taken & 100 & $(87.7)$ & 5 & $(3.37,6.63)$ & \\
\hline \multirow{2}{*}{ Duration of taking $\mathrm{S}_{2} \mathrm{H}_{2} \mathrm{R}_{2}$ regimen } & $\leq 4$ months & 11 & $(9.6)$ & 9 & $(2.53,15.47)$ & 0.572 \\
\hline & $\geq 5$ months & 3 & $(2.6)$ & 6 & $(0.00,14.00)$ & \\
\hline \multirow{2}{*}{ HR Daily Regimen ${ }^{\text {b }}$} & Taken & 40 & $(35.1)$ & 8 & $(4.90,11.10)$ & 0.049 \\
\hline & Not taken & 74 & $(64.9)$ & 4 & $(2.31,5.69)$ & \\
\hline \multirow{2}{*}{ Duration of taking HR regimen } & $\leq 4$ months & 16 & $(14.0)$ & 5 & $(2.65,7.35)$ & 0.436 \\
\hline & $\geq 5$ months & 24 & $(21.1)$ & 9 & $(6.13,11.87)$ & \\
\hline \multirow{2}{*}{ Other drug regimens } & Taken & 7 & $(6.1)$ & 7 & $(0.00,17.27)$ & 0.389 \\
\hline & Not taken & 107 & $(93.9)$ & 6 & $(4.56,7.44)$ & \\
\hline \multirow{2}{*}{ Duration of taking other drug regimen 2} & $\leq 4$ months & 4 & $(3.5)$ & 8 & $(2.12,13.88)$ & 0.062 \\
\hline & $\geq 5$ months & 3 & $(2.6)$ & 3 & $(0.00,6.20)$ & \\
\hline \multirow{2}{*}{ Defaulter Status $^{c}$} & Non- defaulters & 54 & $(47.4)$ & 7 & $(3.80,10.20)$ & 0.006 \\
\hline & Defaulters & 60 & $(52.6)$ & 4 & $(2.48,5.52)$ & \\
\hline
\end{tabular}

${ }^{\mathrm{s}}$ Figure 2a, ${ }^{\mathrm{t}}$ Figure 2b, ${ }^{\mathrm{u}}$ Figure 2c , Streptomycin (S), Isoniazid (H), Rifampicin (R) and Pyrazinamide (Z) [SHRZ], Ethambutol (E), Isoniazid (H), Rifampicin (R) and Pyrazinamide (Z) [EHRZ], Isoniazid (H), Rifampicin (R) and Pyrazinamide (Z) [HRZ], Isoniazid (H) and Rifampicin (R) twice weekly [H2R2], Streptomycin (S), Isoniazid (H) and Rifampicin (R) twice weekly [S2H2R2], *95\% Confidence Interval could not be determined. Kaplan-Meier Survival analysis and Log Rank Test was applied.

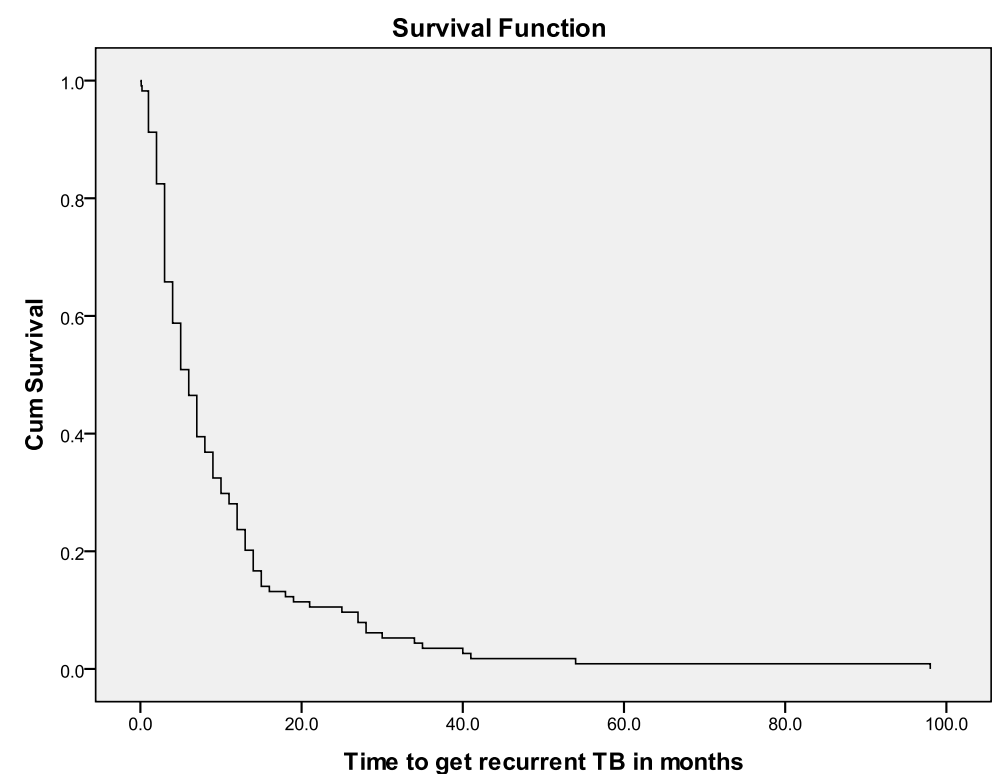

Fig. 1: Kaplan-Meier Survival Curve of Expressing the Probabilities of Getting Recurrent TB. 


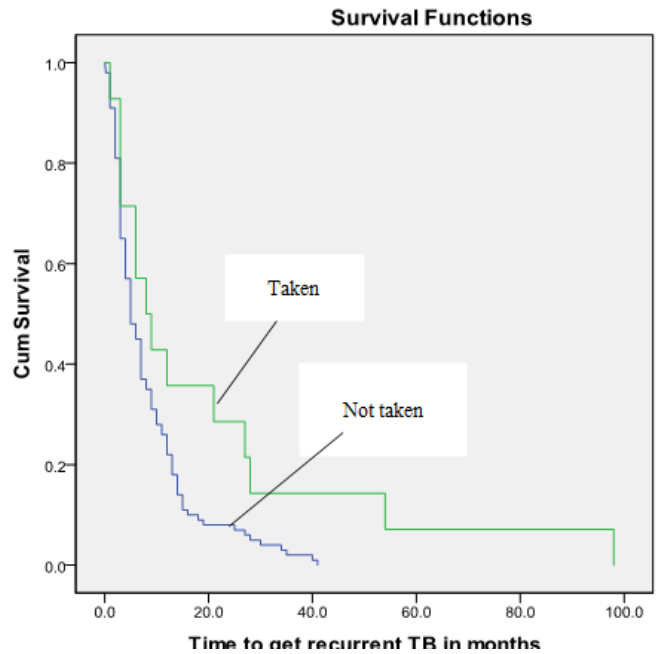

Fig. 2a: Kapalan-Meier Survival curve displaying the median time to get recurrent TB of recipients and non-recipients of $\mathrm{S}_{2} \mathrm{H}_{2} \mathrm{R}_{2}$ drug regimen during the continuation phase.

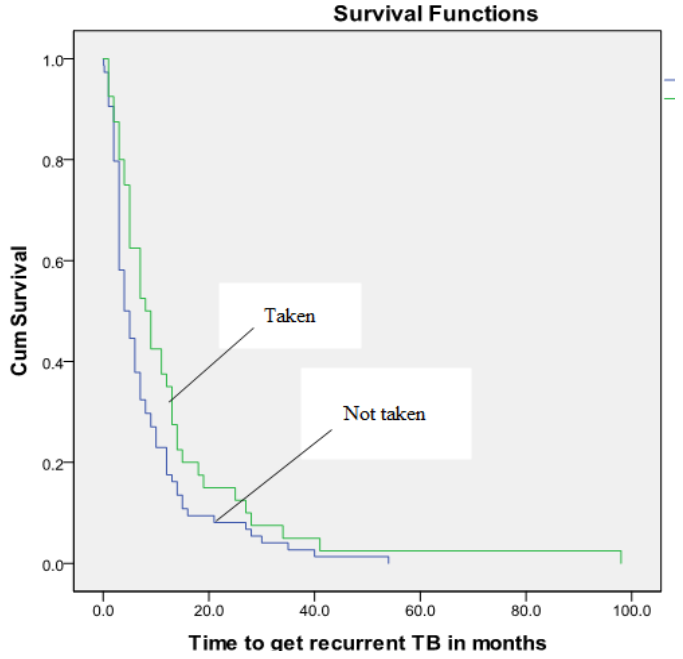

Fig. 2b: Kapalan-Meier Survival curve showing the median time to get recurrent TB of recipients and non-recipients of daily HR drug regimen during the continuation phase.

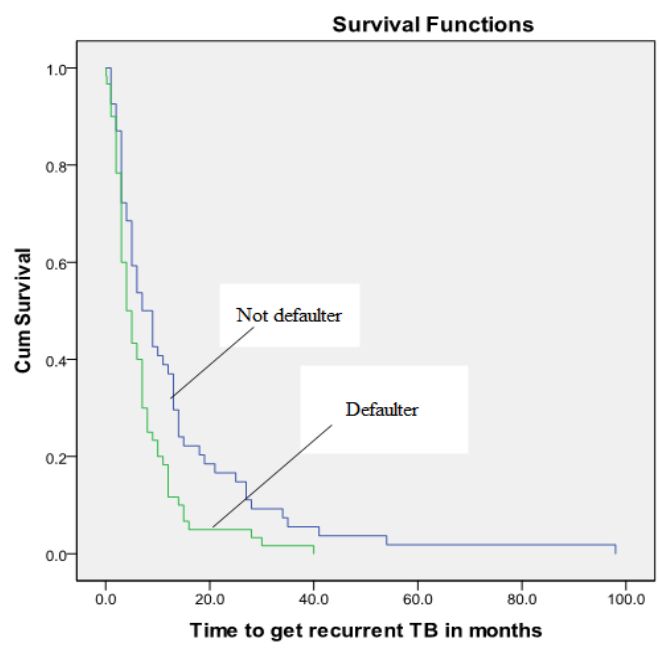

Fig. 2c: Kapalan-Meier Survival curve is presenting the median time to get recurrent TB of defaulters and non-defaulters of treatment.

\section{DISCUSSION}

This study found that the overall median time to develop recurrent TB was 6 months [95\% CI: 4.58, 7.42] after the end of the previous disease episode. Various case definitions of recurrence of TB and diverse inclusion and exclusion criteria, as well as different studied variables, exist among various reports. Most of the previous studies were analyzed only on completely cured patients; whereas this study was done on a heterogeneous group constituting cured not only patients but also defaulters and treatment failure cases. One study in Uganda whose inclusion criteria is the same as this study reported that most instances [about 80\%] had recurrent TB within 8 months of the previous disease episode (Anyama et al., 2007). The analyses done only on cured patients, recurrent TB was found to occur within 6-9 months from the start of treatment (Driver et al., 2001). Again, multiple studies reported that the majority of the cured cases had recurrences within 6 months after completely healed (Thomas et al., 2005; Dholakia et al, 2000; TRC, 1997 and 1983; EABMRC, 1976). Therefore, TB clinicians and health care personnel should be more cautious about the risk of recurrent TB in less than one year after completion of anti-tubercular regimen. Recurrences could be consequences of the inappropriate treatment regimens, inadequate therapy attributable to poor or non-compliance with treatment (Yamagishi \& Toyota, 2009; Kopanoff et al., 1998). This study found that defaulters were found to have recurrent TB earlier than non-defaulters. Studies conducted in South Africa and Brazil also elucidated that the defaulters were found to experience higher recurrent TB (Golub et al., 2008; Verver et al., 2005). The patients having a history of default in the preceding episode are more likely to be defaulters in succeeding episodes also (Chandrasekaran et al., 2006). Poor compliance with treatment resulting in unnecessary prolongation treatment duration, elevated risk of treatment failure, emergence of acquired drug resistance $\mathrm{TB}$, and continue as open case, remains an obstacle to the accomplishment of a TB control program (Vijay et al., 2010). Nowadays, TB clinicians recognized the importance of rifampicin in treating TB. Several studies proved that the better treatment outcomes came out with rifampicin containing regimen than 
bacteriostatic Thiacetazone (T) (EABMRC, 1972 and 1977). The current study found that patients who received $\mathrm{S}_{2} \mathrm{H}_{2} \mathrm{R}_{2}$ drug regimen or daily $\mathrm{HR}$ drug therapy during the continuation phase took a longer duration to get recurrent TB. The findings of the present work advocate the use of 2 first line anti-tubercular drugs: Isoniazid, and Rifampicin; in both initial and continuation phase. Recurrent TB is attributable to reactivation of the previous disease or re-infection with different strains of M. Tuberculosis. The relapse or endogenous reactivation results from low potent regimen or poor compliance even though treatment is completed (Korenromp et al., 2003). On the contrary, exogenous re-infection is related to background TB incidence and HIV prevalence of a country (Cox et al., 2006). One study report suggested that relapse mostly occurred within 6 months following the end of the previous treatment (Jasmer et al., 2004) whereas incidence of exogenous reinfection escalated with the time interval between the end of therapy for the last episode and the start of taking treatment for subsequent one (Shen et al., 2006). There is evidence that there is a relationship between strains of $M$. Tuberculosis and recurrent TB. Beijing strains are prevalent in Asia and North America, and they are mostly related to relapse of the previous infection (Burman et al., 2009; Sun et al., 2006). One study reported that strains of Beijing family were also widespread in West Malaysia but not in East Malaysia (Dale et al., 1999). Consequently, the recurrent cases in this study could be consequences of relapse of the previous infection. Malaysia holds an intermediate burden of TB with a prevalence of 109 [47-173] cases per 100000 population (WHO, 2013) and has 10.88 HIV incidence rate in 2009 (Ministry of Health, 2009). Current research has found that the accessibility and availability to use of DNA fingerprinting method is limited. Thus, our study cannot differentiate the underlying causes of recurrent TB in this studied area, and further research is necessary to investigate the epidemiology of recurrent TB.

\section{ACKNOWLEDGEMENT}

The authors are very thankful to the patients who had participated in the study and also staffs at Chest Clinic HRPZ II for assisting in the data collection data process. All the researchers' cooperation in data management and research report much appreciated. This study obtained funding from Universiti Sains Malaysia. Authors possess no conflict of interest.

\section{REFERENCES}

Anyama N, Sseguya S, Okwera A, El-Naggar WA, Mpagi F, Owino E. The challenge of re-treatment pulmonary tuberculosis at two teaching and referral hospitals in Uganda. Afr Health Sci, 2007; 7(3): 136142. Available at: http://www.ncbi.nlm.nih.gov/pmc/articles/ PMC2269710/pdf/AFHS0703-0136.pdf [Accessed 10 October 2015].

Burman WJ, Bliven EE, Cowan L, Bozeman L, Nahid P, Diem L, Vernon A, \& Tuberculosis Trials Consortium. Relapse Associated with Active Disease Caused by Beijing Strain of Mycobacterium tuberculosis. Emerg Infect Dis, 2009; 15(7): 1061-1067. Available at: http://www.ncbi.nlm.nih.gov/pmc/articles/PMC2744226/pdf/08-1253_ finalR.pdf [Accessed 10 October 2015].
Chaisson RE, Churchyard GJ. Recurrent tuberculosis: relapse, reinfection, and HIV. The J Infect Dis, 2010; 201(5):653-5. doi: 10.1086/650531. Available at: http://jid.oxfordjournals.org/content/ 201/5/653.full.pdf+html [Accessed 10 October 2015].

Chandrasekaan V, Gopi PG, Santha T, Subramani R, Narayanan P. Status of re-registered patients for TB treatment under DOTS programme. Indian J Tuberc, 2006; 54(1):12-6. Available at: http://medind.nic.in/ibr/t07/i1/ibrt07i1p12.pdf [Accessed 10 October 2015].

Cox H, Kebede Y, Allamuratova S, Ismailov G, Davletmuratova Z, Byrne G, Stone C, Niemann S, Rüsch-Gerdes S, Blok L, Doshetov D. Tuberculosis recurrence and mortality after successful treatment: impact of drug resistance. PLoS Med, 2006; 3(10): 384. Available at: http://www.plosmedicine.org/article/fetchObject.action? uri=info\%3Adoi\%2F10.1371\%2Fjournal.pmed.0030384\&representation= PDF [Accessed 10 October 2015].

Dale JW, Nor RM, Ramayah S, Tang TH, Zainuddin ZF. Molecular epidemiology of tuberculosis in Malaysia. J Clin Microb, 1999; 37(5): 1265-1268. Available at: http://www.ncbi.nlm.nih.gov/ pmc/articles/PMC84747/pdf/jm001265.pdf [Accessed 10 October 2015].

Daniel TM. The history of tuberculosis. Respiratory Medicine, 2006; 100: 1862-1870. Available at: http://www.sciencedirect.com/ science/article/pii/S095461110600401X [Accessed 10 October 2015].

Dholakia Y, Danani U, Desai C. Relapse following directly observed therapy short course (DOTS) a following up study. Indian J Tuberc, 2000; 47(4): 233-236. Available at: http://medind.nic.in/ ibr/t00/i4/ibrt00i4p233.pdf

Driver CR, Munsiff SS, Li J, Kundamal N, Osahan SS. Relapse in Persons Treated for Drug-Susceptible Tuberculosis in a Population with HighCoinfection with Human Immunodeficiency Virus in New York City. Clin Infect Dis, 2001; 33(10): 1762-1769. Available at: http://cid.oxfordjournals.org/content/33/10/1762.full.pdf+html [Accessed 10 October 2015].

East African-British Medical Research Council (EABMRC). Controlled clinical trial of four 6-month regimens of chemotherapy for pulmonary tuberculosis. Second report. Second East African-British Medical Research Council Study. Am Rev Respir Dis, 1976; 114(3): 471475 .

East African-British Medical Research Councils (EABMRC). Controlled clinical trial of four short-course (6-month) regimens of chemotherapy for treatment of pulmonary tuberculosis. Lancet, 1972; 1(7816): 1331-1338.

East African-British Medical Research Councils (EABMRC). Results at 5 years of a controlled comparison of a 6-month and a standard 18-month regimen of chemotherapy for pulmonary tuberculosis. Am Rev Respir Dis, 1977; 116(1): 3-8.

El Sahly HM, Wright JA, Soini H, Bui TT, Williams-Bouyer N, Escalante P, Musser JM, Graviss EA. Recurrent TB in Houston, Texas: a population-based study. Int $\mathbf{J}$ Tuberc Lung Dis, 2004; 8(3): 333-340. Available at: http://docstore.ingenta.com/cgi-bin/ds_deliver/1/u/d/ISIS/ 80320556.1/iuatld/ijtld/2004/00000008/00000003/art00010/79007A5A32 1EC922141993024954BB684D221A666A.pdf?link=http://www.ingentac onnect.com/error/delivery\&format=pdf [Accessed 11 October 2015].

Fine PEM, Small PM. Exogenous reinfection in tuberculosis. New Engl J Med. 1999; 341:1226-1227.

Golub JE, Durovni B, King BS, Cavalacante SC, Pacheco AG, Moulton LH, Moore RD, Chaisson RE, Saraceni V. Recurrent tuberculosis in HIV-infected patients in Rio de Janeiro, Brazil. AIDS, 2008; 22(18): 2527-2533. Available at: http://www.ncbi.nlm.nih.gov/ pmc/articles/PMC2603140/pdf/nihms80165.pdf [Accessed 11 October 2015].

Iseman M. Tuberculosis History [Internet]. National Jewish Health, 2013. Available at: http://www.nationaljewish.org /healthinfo/ conditions/tb/history[Accessed 11 October 2015].

Jasmer RM, Bozeman L, Schwartzman K, Cave MD, Saukkonen JJ, Metchock B, Khan A, Burman WJ, Tuberculosis Trials Consortium. Recurrent tuberculosis in the United States and Canada: relapse or reinfection? Am J Respir Crit Care Med, 2004; 170(12): 13601366. Available at: http://www.atsjournals.org/doi/pdf/10.1164/rccm.2004 
08-1081OC [Accessed 11 October 2015].

Kopanoff DE, Snider Jr DE, Johnson M. Recurrent TB: Why do patients develop disease again? USA public health servivces cooperative survey. Am J Public Health, 1998; 78(1): 30-33. Available at: http://www.ncbi.nlm.nih.gov/pmc/articles/PMC1349202/pdf/amjph002400032.pdf [Accessed 11 October 2015].

Korenromp EL, Scano F, Williams BG, Dye C, Nunn P. Effects of human immunodeficiency virus infection on recurrence of tuberculosis after rifampin-based treatment: an analytical review. Clinc Infect Dis, 2003; 37(1): 101-112. Available at: http://cid.oxfordjournals.org/ content/37/1/101.full.pdf+html [Accessed 11 October 2015].

Lambert ML, Hasker E, Deun AV, Roberfroid D, Boelaert M, Stuyft PV. Recurrence in tuberculosis: relapse or reinfection? Lancet Infect Dis, 2003; 3:282-287. Available at: http://ac.elscdn.com/S1473309903006078/1-s2.0-S1473309903006078-main.pdf? tid=c6d290d4-8f36-11e4-b322-00000aab0f6b\&acdnat $=$ 1419842795_943364d4cd922efcf5e358c81eb4a2c [Accessed 11 October 2015].

Mallory KF, Churchyard GJ, Kleinschmidt I, De Cock KM, Corbett EL. The impact of HIV infection on recurrence of tuberculosis in South African gold miners. Int J Tuberc Lung Dis, 200; 4(5): 455-462. Available at: http://docstore.ingenta.com/cgibin/ds_deliver/1/u/d/ISIS/80320579.1/iuatld/ijtld/2000/00000004/0000000 5/art00011/8621844D50C6E18E1419930558F6CACB7FD18BC7C5.pdf? link=http://www.ingentaconnect.com/error/delivery\&format=pdf

[Accessed 11 October 2015].

Millet JP, Shaw E, Orcau A, 'Casals M, Miro JM, Cayla JA, the Barcelona Tuberculosis Recurrence Working Group. Tuberculosis Recurrence after Completion Treatment in a European City: Reinfection or Relapse? PLoS ONE, 2013; 8(6): e64898. doi:10.1371/ journal.pone. 0064898. Available at: http://www.plosone.org/article/fetchObject.action? uri=info\%3 Adoi $\% 2 \mathrm{~F} 10.1371 \% 2$ Fjournal.pone.0064898\&representation $=\mathrm{P}$ DF [Accessed 12 October 2015].

Ministry of Health. Clinical Practice Gudielines. Management of Tuberculosis. 3rd Edition. Malaysia Health Technology Assessment Section (MaHTAS), Medical Development Division, Ministry of Health Malaysia, Level 4, Block E1, Precinct 1, Federal Government Administrative Centre 62590, Putrajaya, Malaysia. 2012. Available at: http://www.moh.gov.my/attachments/8612.pdf [Accessed 12 October 2015].

Ministry of Health. Health Facts 2009. Available at: http://vlib.moh.gov.my/cms/documentstorage/com.tms.cms.document.Doc ument_4add873f-c0a81049-13ce5ad0-9b5bdb32/2009.pdf

Panjabi R, Comstock GW, Golub JE. Recurrent tuberculosis and its risk factors: adequately treated patients are still at high risk. Int $\mathrm{J}$ Tuberc Lung Dis, 2007; 11(8): 828-837. Available at: http://www.researchgate.net/publication/6133784_Recurrent_tuberculosis _and_its_risk_factors_adequately_treated_patients_are_still_at_high_risk [Accessed 12 October 2015].

Shen G, Xue Z, Shen X, Sun B, Gui X, Shen M, Mei J, Gao Q. Recurrent tuberculosis and exogenous reinfection, Shanghai, China. Emerg Infect Dis, 2006; 2(11): 1776-1778. Available at: http://www.ncbi.nlm.nih.gov/pmc/articles/PMC3372325/pdf/05-1207.pdf

Sun YJ, Lee ASG, Wong SY, Paton NI. Association of Mycobacterium tuberculosis Beijing genotype with tuberculosis relapse in Singapore. Epidemiol Infect, 2006; 134(2): 329-332. Available at: http://www.ncbi.nlm.nih.gov/pmc/articles/PMC2870406/pdf/S095026880 500525Xa.pdf [Accessed 12 October 2015].

Thomas A, Gopi PG, Santha T, Chandrasekaran V, Subramani R, Selvakumar N, Sadacharam K, Narayanan PR. Predictors of relapse among pulmonary TB in patients treated in a DOTS programme in South India. Int $\mathrm{J}$ Tuberc Lung Dis, 2005; 9(5):556-561. Available at: http://docstore.ingenta.com/cgi-bin/ds_deliver/1/u/d/ISIS/80321756.1/ iuatld/ijtld/2005/00000009/00000005/art00016/52B571555964205214199 3987407302C35E9E08700.pdf?link=http://www.ingentaconnect.com/erro r/delivery\&format=pdf [Accessed 12 October 2015].

Tuberculosis Research Centre (TRC). A controlled clinical trial of oral short-course regimens in the treatment of sputum-positive pulmonary tuberculosis. Tuberculosis Research Centre. Int J Tuberc Lung
Dis, 1997; 1(6): 509-517. Available at: http://docstore.ingenta.com/cgibin/ds_deliver/1/u/d/ISIS/80321827.1/iuatld/ijtld/1997/00000001/0000000 6/art00007/7754C218C7B4F864141994019730BB7669EB7F1838.pdf?lin $\mathrm{k}=\mathrm{http}: / / \mathrm{www}$.ingentaconnect.com/error/delivery\&format=pdf [Accessed 12 October 2015].

Tuberculosis Research Centre (TRC). Study of chemotherapy regimens of 5 and 7 months' duration and the role of corticosteroids in the treatment of sputum-positive patients with pulmonary tuberculosis in South India. Tubercle, 1983; 64(2): 73-91. Available at: http://ac.elscdn.com/0041387983900326/1-s2.0-0041387983900326-

main.pdf?_tid=9a08b35a-901a-11e4-a802-

00000aab0f27\&acdnat=1419940645_afb8443dddffe68a1db9041568483c5 8 [Accessed 12 October 2015].

Uddin SN, Hossain SJ, Huda MN, Rahman MH, Ali ME Consequence on Treatment of TB Patients Affected by HIV/AIDS A Conceptual Research. Am J Infect Dis, 2006; 2 (4): 210-218. Available at: http://www.researchgate.net/publication/26460063_Consequence_on_Trea tment_of_TB_Patients_Affected_by_HIVAIDS_A_Conceptual_Research [Accessed 12 October 2015].

Van Rie A, Warren R, Richardson M, Victor TC, Gie RP, Enarson DA, Beyers N, van Helden PD. Exogenous reinfection as a cause of recurrent tuberculosis after curative treatment. N Eng J Med, 1999; 341: $1174-1179$

Verver S, Warren RM, Beyers N, Richardson M, van der Spuy GD, Borgdorff MW, Enarson DA, Behr MA, van Helden PD. Rate of Reinfection Tuberculosis after Successful Treatment Is Higher than Rate of New Tuberculosis. Am J Res Crit Care Med, 2005; 171(12): 14301435. Available at: http://www.atsjournals.org/doi/pdf/10.1164/ rccm.200409-1200OC [Accessed 12 October 2015].

Vijay S, Kumar P, Chauhan LS, Vollepore BH, Kizhakkethil UP, Rao SG. Risk factors Associated with Default among New Smear Positive TB Patients Treated Under DOTS in India. PLoS One, 2010; 5(4):e10043. Available at: http://www.plosone.org/article/ fetchObject.action?uri=info\%3Adoi\%2F10.1371\%2Fjournal.pone.001004 3 \&representation $=\mathrm{PDF}$

World Health Organization. Global tuberculosis control. 2010. Available at: http://reliefweb.int/sites/reliefweb.int/files/resources/ F530290AD0279399C12577D8003E9D65-Full_Report.pdf [Accessed 12 October 2015].

World Health Organization. Malaysia TB country profile. 2013. Available at: https://extranet.who.int/sree/Reports?op=Replet\&name=/ WHO_HQ_Reports/G2/PROD/EXT/TBCountryProfile\&ISO2=my\&outty pe $=$ pdf [Accessed 12 October 2015].

World Health Organization. Media Centre. WHO launches new stop TB strategy to fight the global tuberculosis epidemic. 2006. Available at: $\quad$ http://www.who.int/mediacentre/news/releases/2006/pr12/en/ [Accessed 12 October 2015].

Yamagishi F, Toyota M. Research and control of relapse tuberculosis cases. Kekkaku (Tuberculosis), 2009; 84(12): 767-768.

\footnotetext{
How to cite this article:

Naing NN, Aung MMT, Rusli AM, Zuki MJM, Arfah NW, Haque M. The Median Time to Develop Recurrent Tuberculosis at a Tertiary Hospital in Kota Bharu, Kelantan, Malaysia. J App Pharm Sci, 2016; 6 (02): 097-103.
} 